\title{
First record of parasitoids (Hymenoptera: Braconidae) associated with Anastrepha barbiellinii Lima, 1938 (Diptera: Tephritidae)
}

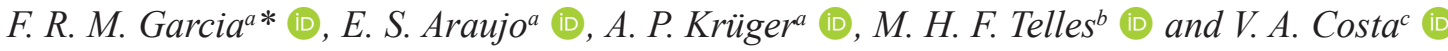 \\ ${ }^{a}$ Universidade Federal de Pelotas - UFPel, Departamento de Ecologia, Zoologia e Genética, Capão do Leão, RS, Brasil \\ 'Instituto de Biociências, Universidade Federal de Rio Grande do Sul - UFRGS, Porto Alegre, RS, Brasil \\ 'Instituto Biológico, Unidade Laboratorial de Referência em Controle Biológico, Campinas, SP, Brasil \\ *e-mail: flavio.garcia@ufpel.edu.br
}

Received: February 18, 2020 - Accepted: May 22, 2020 - Distributed: November 30, 2021

Tephritidae is one of the most important Diptera families as it encompasses pest species that cause great economic losses in fruit crops worldwide (Dias et al., 2018; Monteiro et al., 2019). Interestingly, Brazil is home to many species of native fruit fly parasitoids, belonging to the Braconidae, Diapriidae, Figitidae and Pteromalidae families (Garcia and Ricalde, 2013; Ongaratto et al., 2020). Scientific efforts aimed at assessing the tritrophic relations among host plants, tephritid fruit flies and parasitoids can contribute to the development of biological pest control strategies (Garcia and Ricalde, 2013). However, for more than $77 \%$ of the 121 species of the Anastrepha genus registered in Brazil, there is a lack of data regarding their associated parasitoid species (Zucchi, 2008). Pereskia aculeata Mill. (Cactaceae) is native to the Brazilian flora, commonly known in Brazil as "ora-pro-nóbis" (Almeida and Corrêa, 2012). The interest of pharmaceutical and food industries on $P$. aculeata has increased in the last years, due to the high content of proteins, essential amino acids, minerals and vitamins in its leaves (Almeida and Corrêa, 2012). Pereskia aculeata fruits can be infested by the dipterous: Anastrepha barbiellinii (Lima, 1938), Ceratitis capitata (Wiedemann, 1824) and Neosilba sp. (Marsaro Júnior et al., 2011).

In the current study, thirty fruits of $P$. aculeata were collected at the Zoobotânica Foundation in Porto Alegre Rio Grande do Sul, Brazil (30 03'S, 51 $\left.{ }^{\circ} 10^{\prime} \mathrm{W}\right)$. Individual fruits were put in plastic containers with a thin layer of vermiculite in the bottom, and closed with voile fabric. The recovered puparia were moved to individual plastic containers with lightly moist vermiculite in the bottom until adult emergence of flies and/or parasitoids (Leonel Júnior et al., 1995). Only in those fruits in which one species of tephritid emerged, the associations between one species of parasitoid and fruit fly were considered valid. In the laboratory of Insect Ecology of the Federal University of Pelotas, the insects were counted, and preserved in $70 \%$ hydrated alcohol for later identification. Fruit fly specimens were identified at the species level by diagnosis of the morphological characteristics of the females (Zucchi, 2000). The Braconidae species were identified according to the key of Wharton and Yoder (2016).
The only species of fruit fly recovered in this study was A. barbiellinii (Diptera: Tephritidae), amounting 28 individuals (9 males and 19 females). In total, 13 Braconidae parasitoids emerged from the puparium. Three species of parasitoids were identified: Doryctobracon

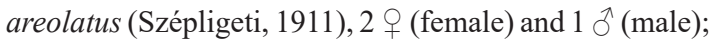
Doryctobracon brasiliensis (Szépligeti, 1911), 3 đ̊ and 5 o; and Utetes anastrephae (Viereck, 1913), 2 ․ This study constitutes the first record of the D. areolatus and $U$. anastrephae parasitoids associated with $A$. barbiellinii. In a previous study, Marsaro Jr. et al. (2011) could not confirm if $D$. areolatus was parasitizing $A$. barbiellinii due to the emergence of other Tephritidae species in their samples. Moreover, the association between $D$. brasiliensis and $A$. barbiellinii was observed in a study conducted in Rio Grande do Sul (Marsaro Júnior, 2014). According to Aluja et al. (2014), P. aculeata could be classified as a parasitoid reservoir plant, because $A$. barbiellinii larvae use its fruits, of non-commercial value, with the subsequent attraction and multiplication of parasitoid species capable to attack other tephritids that are pests of fruits grown commercially. Therefore, $P$. aculeata might play a relevant role in the ecological balance of tephritid populations in fruit orchards. Thus, the data presented in this scientific note increases the knowledge about the tritrophic relationships among Tephritidae flies, hosts plants and natural enemies in Brazil.

\section{References}

ALMEIDA, M.E.F. and CORRÊA, A.D., 2012. Utilização de cactáceas do gênero Pereskia na alimentação humana em um município de Minas Gerais. Ciência Rural, vol. 42, no. 4, pp. 751-756. http://dx.doi.org/10.1590/S0103-84782012000400029.

ALUJA, M., SIVINSKI, J., VAN DRIESCHE, R., ANZURESDADDA, A. and GUILLÉN, L., 2014. Pest management through tropical tree conservation. Biodiversity and Conservation, vol. 23, no. 4, pp. 831-853. http://dx.doi.org/10.1007/s10531-014-0636-3.

DIAS, N.P., ZOTTI, M.J., MONTOYA, P., CARVALHO, I.R. and NAVA, D.E., 2018. Fruit fly management research: a systematic review of monitoring and control tactics in the world. Crop Protection, vol. 112, pp. 187-200. http://dx.doi.org/10.1016/j. cropro.2018.05.019. 
GARCIA, F.R.M. and RICALDE, M.P., 2013. Augmentative biological control using parasitoids for fruit fly management in Brazil. Insects, vol. 4, no. 1, pp. 55-70. http://dx.doi.org/10.3390/ insects4010055. PMid:26466795.

LEONEL JÚNIOR, F.L., ZUCCHI, R.A. and WHARTON, R.A., 1995. Distribution and tephritid hosts (Diptera) of braconid parasitoids (Hymenoptera) in Brazil. International Journal of Pest Management, vol. 41, no. 4, pp. 208-213. http://dx.doi.org/10.1080/09670879509371951.

MARSARO JÚNIOR, A.L., 2014. Novos registros de hospedeiros de moscas-das-frutas (Diptera: Tephritidae) para o Rio Grande do Sul. Revista de Agricultura, vol. 89, no. 1, pp. 65-71. http:// dx.doi.org/10.37856/bja.v89i1.116.

MARSARO JÚNIOR, A.L., SOUZA FILHO, M.F., SILVA, R.A. and STRIKIS, P.C., 2011. First report of natural infestation of Pereskia aculeata Mill. (Cactaceae) by Ceratitis capitata (Wiedemann) (Diptera: Tephritidae) in Brazil. Revista de Agricultura, vol. 86, no. 2, pp. 151-154. http://dx.doi.org/10.37856/bja.v86i2.2866.

MONTEIRO, L.B., TOMBA, J.A.S., NISHIMURA, G., MONTEIRO, R.S., FOELKEL, E. and LAVIGNE, C., 2019. Faunistic analyses of fruit fly species (Diptera: Tephritidae) in orchards surrounded by Atlantic Forest fragments in the metropolitan region of Curitiba,
Paraná State, Brazil. Brazilian Journal of Biology $=$ Revista Brasileira de Biologia, vol. 79, no. 3, pp. 395-403. http://dx.doi. org/10.1590/1519-6984.178458. PMid:30231137.

ONGARATTO, S., PINTO, K.J., MÂNICA-BERTO, R., NÖRNBERG, S.D., GONÇALVES, R.S., GARCIA, M.S. and NAVA, D.E., 2020. Influence of the host diet on the performance of Doryctobracton areolatus (Hymenoptera: braconidae). Brazilian Journal of Biology $=$ Revista Brasileira de Biologia. In press. http://dx.doi.org/10.1590/15196984.217968. PMid:31778480.

WHARTON, R.A. and YODER, M.J., 2016. Parasitoids of fruitinfesting Tephritidae [online]. [viewed 7 March 2016] Available from: http://paroffit.org

ZUCCHI, R.A., 2000. Taxonomia. In: A. MALAVASI and R.A. ZUCCHI, eds. Mosca-das-frutas de importância econômica no Brasil: conhecimento básico e aplicado. Ribeirão Preto: Holos, cap. 1, pp. 13-24.

ZUCCHI, R.A., 2008 [viewed 6 May 2019]. Fruit flies in Brazil: Anastrepha species their host plants and parasitoids [online]. Available from: www.lea.esalq.usp.br/anastrepha/ 